\title{
Redescription of Digalodon rubidgei, an emydopoid dicynodont (Therapsida, Anomodontia) from the Late Permian of South Africa
}

\author{
C. F. Kammerer ${ }^{1}$, K. D. Angielczyk ${ }^{2}$, and J. Fröbisch ${ }^{1}$ \\ ${ }^{1}$ Museum für Naturkunde, Invalidenstraße 43, 10115 Berlin, Germany \\ ${ }^{2}$ Field Museum of Natural History, 1400 South Lake Shore Drive, Chicago, Illinois 60605, USA \\ Correspondence to: C. F. Kammerer (christian.kammerer@mfn-berlin.de)
}

Received: 26 September 2014 - Revised: 10 December 2014 - Accepted: 12 December 2014 - Published: 22 January 2015

\begin{abstract}
The Late Permian dicynodont Digalodon rubidgei Broom and Robinson, 1948, is redescribed based on reanalysis of the holotype and newly recognized referable specimens. Digalodon can be diagnosed by the presence of a long "beak" sharply demarcated from the caniniform process; an extremely tall zygomatic ramus of the squamosal, with a thickened, "folded-over" dorsal margin; raised parietal "lips" along the lateral edges of the pineal foramen; and a broad posterolateral expansion of the parietal, excluding the postorbital from the back of the skull roof. Inclusion of Digalodon in a recent analysis of anomodont phylogeny recovers it as a kistecephalian emydopoid, specifically as the sister taxon to the clade containing the remaining kistecephalians. Four definite specimens of Digalodon are known, but several additional specimens lacking tusks, the swollen pineal "lips", and a thickened zygoma may represent sexually dimorphic females or juveniles. Specimens of Digalodon are restricted to the central portion of the Karoo Basin, in the area around Graaff-Reinet, and are part of a characteristic fauna probably representing a limited time span.
\end{abstract}

\section{Introduction}

Emydopoidea is one of the three major groups of "advanced" dicynodont therapsids (therochelonians sensu Kammerer and Angielczyk, 2009). Unlike the other therochelonians, which are primarily large-bodied ( $>1 \mathrm{~m}$ body length) animals, emydopoids are typically small, with only a single genus (Dicynodontoides) attaining a skull length greater than $15 \mathrm{~cm}$ (Angielczyk et al., 2009). Four families of emydopoids are known: the basal Emydopidae (containing Emydops) and the three clades united in Kistecephalia - Kingoriidae (Dicynodon- toides and Kombuisia), Myosauridae (Myosaurus), and the fossorial Cistecephalidae (Cistecephalus, Cistecephaloides, and Kawingasaurus). Emydopoid taxonomy and anatomy have been extensively studied in the past few decades and their phylogenetic relationships are generally well understood (Cox, 1959, 1972; Cluver, 1978; Hammer and Cosgriff, 1981; Angielczyk et al., 2005, 2009; Fröbisch, 2007; Fröbisch and Reisz, 2008). Emydopoids are common in the early Late Permian of South Africa, with hundreds of specimens recovered from the Tropidostoma and Cistecephalus assemblage zones (AZs) of the Karoo Basin (Smith et al., 2012). In the latest Permian (Dicynodon AZ), however, emydopoids have traditionally been considered a rare faunal component, part of a general pattern of extinction of small dicynodonts (e.g., Emydops, but also including Diictodon and Pristerodon) well before the terminal Permian extinction (Smith and Botha-Brink, 2014). Despite the extinction of these well-known genera, there are various enigmatic, emydopoid-like small dicynodonts from the Late Permian that have been historically understudied and may influence this supposed pattern.

Broom and Robinson (1948) described Digalodon rubidgei based on a single skull (RC 76) collected in the $\mathrm{Di}$ cynodon AZ of Ferndale, Graaff-Reinet. The new taxon was diagnosed primarily by characters of the intertemporal region. For example, the lengthy intertemporal portion of the frontals in RC 76 was contrasted with the condition in "all typical Dicynodonts" [sic] in which "the frontals lie mainly between the orbits" (Broom and Robinson, 1948:402). It should be noted that the frontal morphology of RC 76 is actually very similar to that of the common Permian dicynodont Pristerodon, and a long contribution of the frontal to the intertemporal region is also present in myosaurids and ciste- 
cephalids. In their defense, Broom and Robinson (1948:404) considered at least Myosaurus and Cistecephalus to be atypical dicynodonts, "much specialized and degenerate types", and even mentioned that they "may have evolved from a dicynodont like Digalodon". Broom and Robinson (1948) also distinguished Digalodon from Dicynodon (sensu lato, including Diictodon, Oudenodon, and various other taxa see Kammerer et al., 2011) by its broad parietal exposure in the intertemporal region. They noted (correctly) that this represents a primitive character common in small-bodied dicynodonts like Pristerodon and most emydopoids.

Following its initial description, Digalodon was largely ignored by subsequent workers, appearing primarily in comprehensive lists of Karoo vertebrates or therapsid taxa (e.g., Haughton and Brink, 1954; Romer, 1956; Lehman, 1961). Two attempts were made to refer the mysterious type specimen of D. rubidgei to a better-known dicynodont taxon. Cluver and King (1983) noted a few similarities between $D i$ galodon and Aulacephalodon, leading King (1988) to consider them tentative synonyms (presumably considering the much smaller Digalodon a juvenile of the latter genus). Brink (1986) listed Digalodon rubidgei as a junior synonym of Dicynodontoides parringtoni (i.e., Dicynodontoides recurvidens) without comment. Most recently, Angielczyk et al. (2009) reconsidered the synonymy of Digalodon and Dicynodontoides, and concluded that Digalodon represents a distinct taxon possibly related to Emydops. Furthermore, they referred two additional specimens to D. rubidgei (RC 469 and USNM 22941), but noted that these referrals were tentative pending a full redescription of the species.

Here, we completely redescribe the cranial morphology of Digalodon rubidgei based on the holotype. Additionally, we address the status of additional skulls that may be referable to Digalodon and consider the geographic and stratigraphic range of this taxon and its phylogenetic position.

Institutional Abbreviations - B, Bremner Collection, Graaff-Reinet Museum, Graaff-Reinet, South Africa; BP, Evolutionary Studies Institute (formerly Bernard Price Institute for Palaeontological Research), University of the Witwatersrand, Johannesburg, South Africa; RC, Rubidge Collection, Wellwood, Graaff-Reinet District, South Africa; USNM, National Museum of Natural History, Smithsonian Institution, Washington, D.C., USA.

\section{Systematic paleontology}

Synapsida Broom, 1905

Anomodontia Owen, 1860a

Dicynodontia Owen, 1860a

Superfamily Emydopoidea van Hoepen, 1934

Revised definition: Emydops arctatus (Owen, 1876) and all taxa more closely related to it than to Oudenodon bainii
Owen, 1860b, Dicynodon lacerticeps Owen, 1845, Diictodon feliceps (Owen, 1876), or Endothiodon bathystoma Owen, 1876 (modified from Kammerer and Angielczyk, 2009). Kammerer and Angielczyk's (2009) definition of Emydopoidea used only Oudenodon and Dicynodon as external specifiers, based on existing phylogenies (e.g., Angielczyk, 2001, 2007; Angielczyk and Kurkin 2003; Fröbisch, 2007) that reconstructed pylaecephalids (Diictodon and allies) and endothiodontids near the base of Dicynodontia. More recent analyses (Kammerer et al., 2011, 2013) have recovered a sister-group relationship between pylaecephalids and the traditional emydopoids (i.e., Emydops + Kistecephalia). Furthermore, recent discoveries (Castanhinha et al., 2013; Cox and Angielczyk, 2015) have revealed a distribution of character states that blurs the traditional morphological distinctions between "endothiodonts" (sensu Kammerer and Angielczyk, 2009) and emydopoids (e.g., similar palatine pad morphologies and premaxillary teeth in Niassodon, a taxon Castanhinha et al. recovered as a kingoriid emydopoid). We consider it in the best interests of taxonomic stability to refine the definition of the robustly diagnosed group Emydopoidea to better ensure its traditional composition is maintained.

Digalodon Broom and Robinson, 1948

Type species: Digalodon rubidgei Broom and Robinson, 1948.

Diagnosis: as for type and only species.

Digalodon rubidgei Broom and Robinson, 1948

Figures 1-4, 6-10

Holotype: RC 76, a complete, somewhat sheared cranium from Ferndale, Graaff-Reinet, Eastern Cape Province. This specimen and all referred material were found in rocks of the Beaufort Group in the Karoo Basin of South Africa.

Referred material: B 42, a worn skull and vertebra from Libertas, Nietgegund, Pearston, Eastern Cape Province; $\mathrm{BP} / 1 / 157$, a poorly prepared skull and lower jaws from Hoeksplaas, Murraysburg, Western Cape Province; RC 469, a largely unprepared skull missing the snout from Rooiwal, Richmond, Northern Cape Province. There are four additional specimens that deviate slightly in morphology from the holotype and referred specimens of D. rubidgei but probably pertain to this species (see below): USNM 22941, a somewhat flattened skull from Richmond, Northern Cape Province; RC 303, 304, and 306, three small, partially preserved skulls from Glencliff, Aberdeen, Eastern Cape Province.

Diagnosis: a small dicynodont (maximum basal skull length $10 \mathrm{~cm}$ ) that can be identified as an emydopoid by the presence of a precaniniform embayment of the palatal rim and shovel-shaped jaw symphysis. Digalodon rubidgei can be distinguished from all known emydopoids by the presence of paired anterior palatal ridges on the premaxilla (reversal to the non-emydopoid plesiomorphic state), a long "beak" 

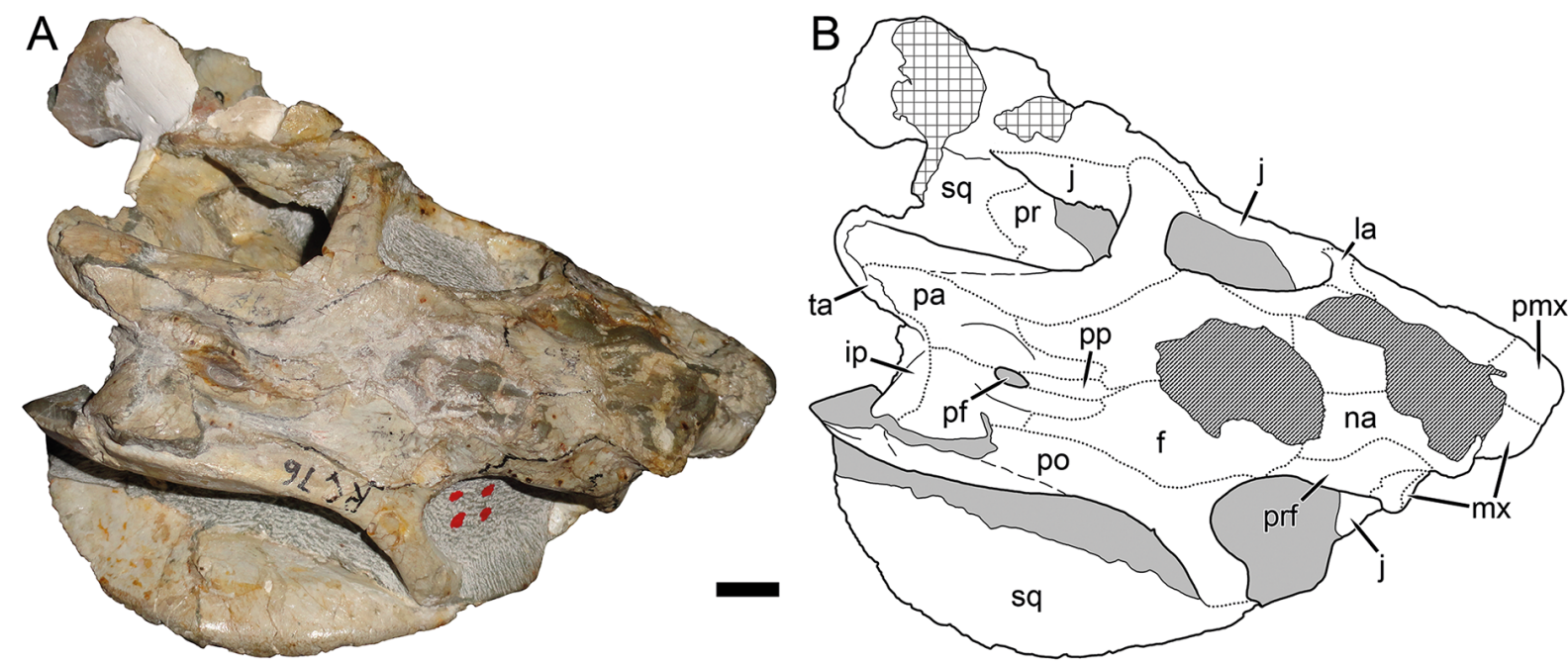

Figure 1. Photograph (a) and interpretive drawing (b) of RC 76, the holotype of Digalodon rubidgei, in dorsal view. Gray indicates matrix, hatching indicates damaged bone surface, and cross-hatching indicates plaster. Scale bar equals $1 \mathrm{~cm}$. Abbreviations: $\mathrm{f}$, frontal; ip, interparietal; j, jugal; la, lacrimal; mx, maxilla; na, nasal; pa, parietal; pf, pineal foramen; pmx, premaxilla; po, postorbital; pp, preparietal; pr, prootic; prf, prefrontal; sq, squamosal; ta, tabular.

sharply demarcated from the caniniform process, and an extremely tall zygomatic ramus of the squamosal, with a thickened, "folded-over" dorsal margin (convergent with geikiid cryptodonts). Distinguished from all emydopoids other than Compsodon by the presence of raised parietal "lips" along the lateral edges of the pineal foramen. Distinguished from all non-cistecephalid emydopoids by the short frontal contribution to the orbital margin. Digalodon has a broad posterolateral expansion of the parietal, excluding the postorbital from the back of the skull roof to an even greater degree than in Myosaurus and cistecephalids.

\section{Description}

The following redescription of Digalodon rubidgei is based on the holotype cranium, RC 76. The holotype is fairly well preserved and (compared with other Broom types of similar age) well prepared, with clear sutures visible over much of the skull (Figs. 1-4). The skull is almost complete, missing only part of the left temporal arch. However, the bone surface of the skull is damaged in several places, particularly on the interorbital region, the dorsal surface of the snout, and the zygoma. The palatal surface has been somewhat overprepared, losing fine surface detail. The skull has also suffered postmortem shear, such that the right side of the skull has moved slightly anteriorly relative to the left. The skull is short (as in most emydopoids) and roughly "heart-shaped" in dorsal view. The intertemporal region is slightly broader than the interorbital in this specimen.

The premaxilla has, as Broom and Robinson (1948) noted, only a short contribution to the lateral surface of the snout, similar to other emydopoids (Fig. 2). The extent of the as- cending process of the premaxilla is uncertain in $\mathrm{RC} 76$ because this region is damaged. Because of this damage, the morphology of the external naris and septomaxilla is also unknown. Ventrally, the premaxilla forms a broad secondary palate as is typical of dicynodonts (Fig. 3). On the right side, the premaxilla appears to be similar to that of Emydops, with a laterally flaring portion anterior to the caniniform process separated from a short, squared-off anterior tip. This morphology is not present on the left side, however; it is uncertain whether this is the result of damage. Paired anterior palatal ridges are present on the premaxilla, although they are weak (possibly due to overpreparation). They bow slightly outwards at their posterior terminus and do not contact the posterior median palatal ridge. It is unclear whether lateral anterior palatal ridges (as are present in other emydopoids) were present. Only a faint ridge is present on the palatal surface of the left maxilla, but given general overpreparation of the palate it is probable that more defined ridges were originally present on both sides (especially given their presence in the specimen B 42, for which see below). The posterior median palatal ridge is a narrow, blade-like element partially obscured by matrix. It extends anteriorly to a point between the tusks.

The premaxilla and maxilla form a turtle-like "beak" anterior to the caniniform processes. The ventral margin of this beak is essentially horizontal for its entire length, unlike the hooked beak tips of many other dicynodonts. The length of the beak is somewhat exaggerated in left lateral view (Fig. 2a) because of shear; in life it would have been intermediate in length between what is shown in Fig. 2a and c. Even with this distortion accounted for, the beak is significantly longer than in other known emydopoids. There is a 

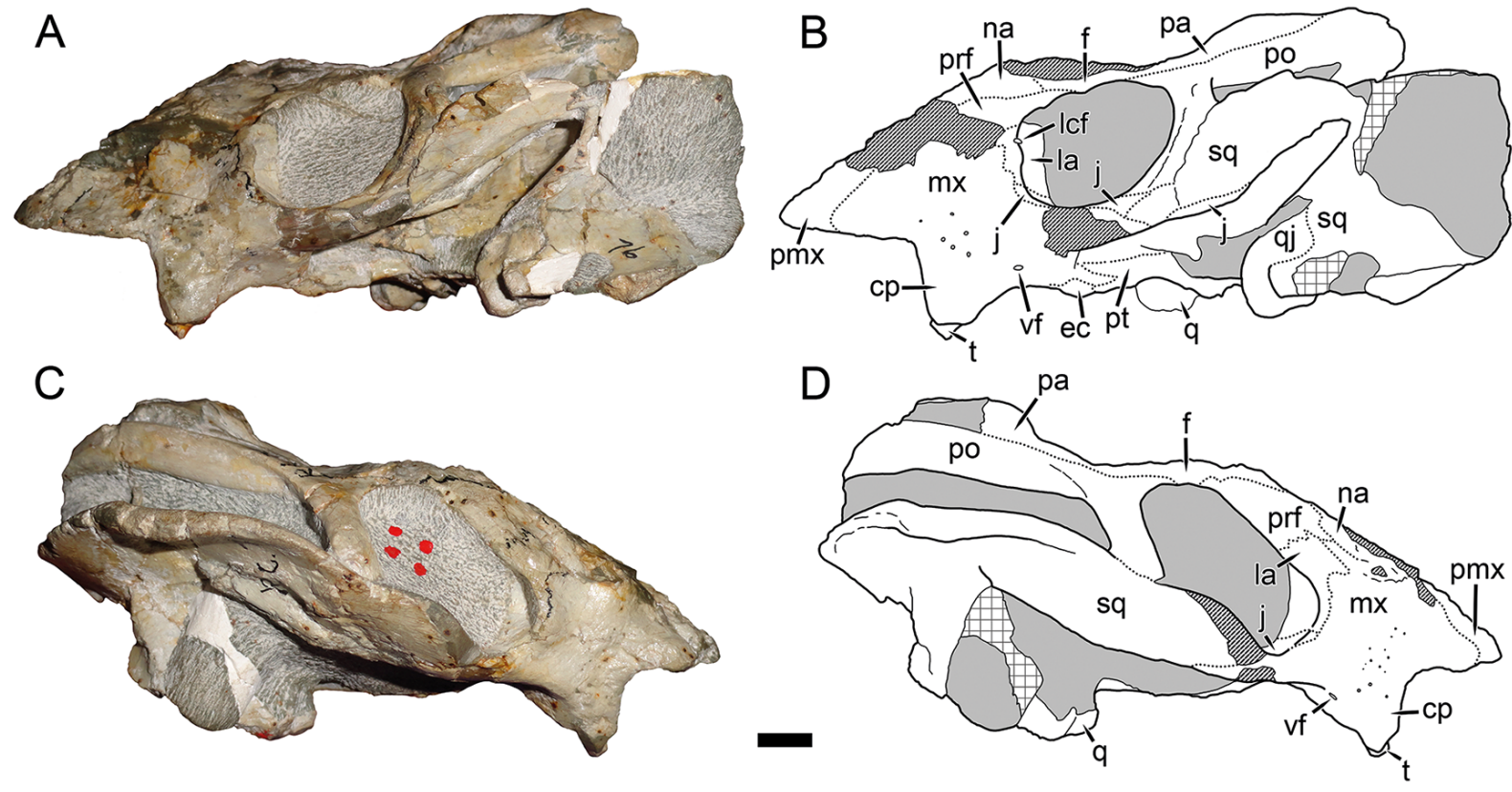

Figure 2. RC 76, the holotype of Digalodon rubidgei, in left lateral (a, photograph; b, interpretive drawing) and right lateral (c, photograph; d, interpretive drawing) views. Gray indicates matrix, hatching indicates damaged bone surface, and cross-hatching indicates plaster. Scale bar equals $1 \mathrm{~cm}$. Abbreviations: cp, caniniform process; ec, ectopterygoid; f, frontal; j, jugal; la, lacrimal; lcf, lacrimal foramen; mx, maxilla; na, nasal; pa, parietal; pmx, premaxilla; po, postorbital; prf, prefrontal; pt, pterygoid; q, quadrate; qj, quadratojugal; sq, squamosal; t, tusk; vf, vascular foramen.
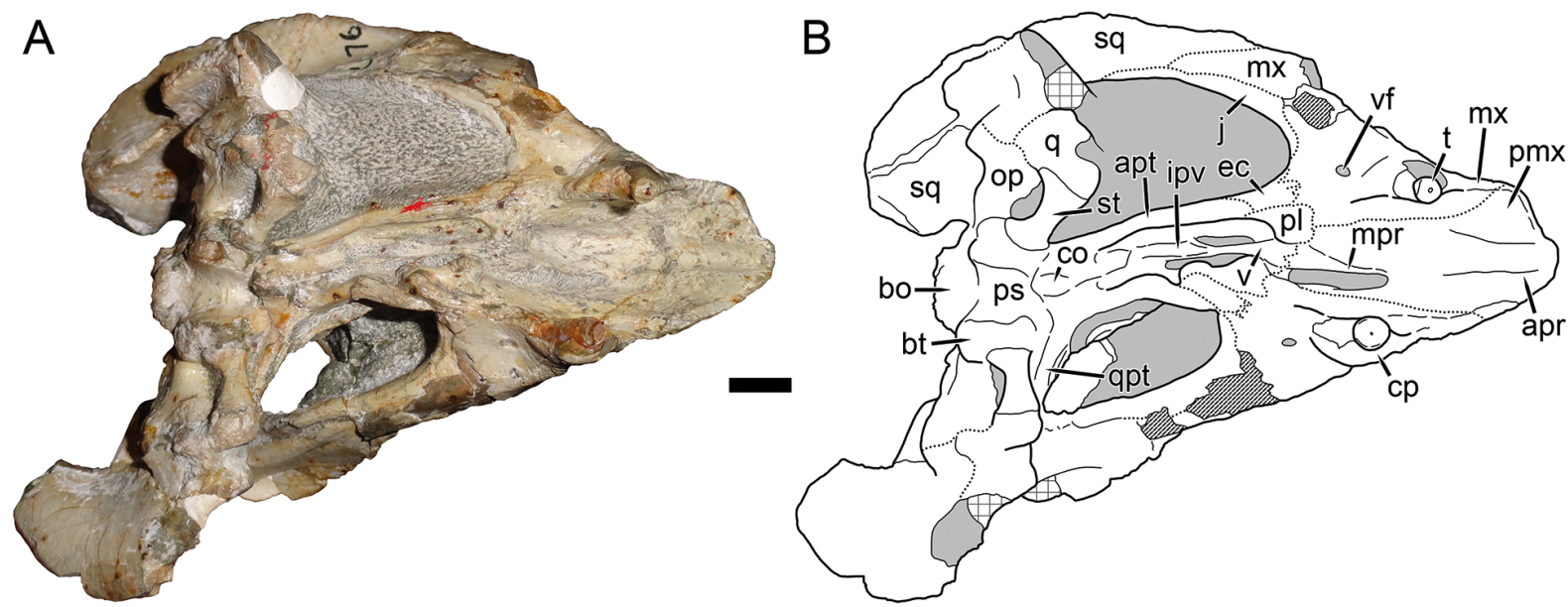

Figure 3. Photograph (a) and interpretive drawing (b) of RC 76, the holotype of Digalodon rubidgei, in ventral view. Gray indicates matrix, hatching indicates damaged bone surface, and cross-hatching indicates plaster. Scale bar equals $1 \mathrm{~cm}$. Abbreviations: apr, anterior palatal ridge; apt, anterior pterygoid ramus; bo, basioccipital; bt, basal tuber; co, crista oesophagea; cp, caniniform process; ec, ectopterygoid; ipv, interpterygoid vacuity; j, jugal; mpr, posterior median palatal ridge; mx, maxilla; op, opisthotic; pl, palatine; pmx, premaxilla; ps, parasphenoid; q, quadrate; qpt, quadrate pterygoid ramus; sq, squamosal; st, stapes; t, tusk; v, vomer; vf, vascular foramen.

sharp $\left(\sim 100^{\circ}\right)$ demarcation between the ventral margin of the beak and the caniniform process, but the alveolar margin is smooth; there is not a distinct notch as in pylaecephalids.

A well-developed maxillary caniniform process houses the tusk. Although this process is directed ventrally, the tusks are angled anteroventrally (Fig. 2). A series of small vascu- lar foramina are present on the lateral surface of the caniniform process, probably associated with the tusk root. It is also possible that these foramina were associated with the keratinous beak, as is usually inferred for dicynodonts (Kemp, 1982; King, 1988). However, if these foramina were associated with an overlying rhamphotheca, we would expect them 

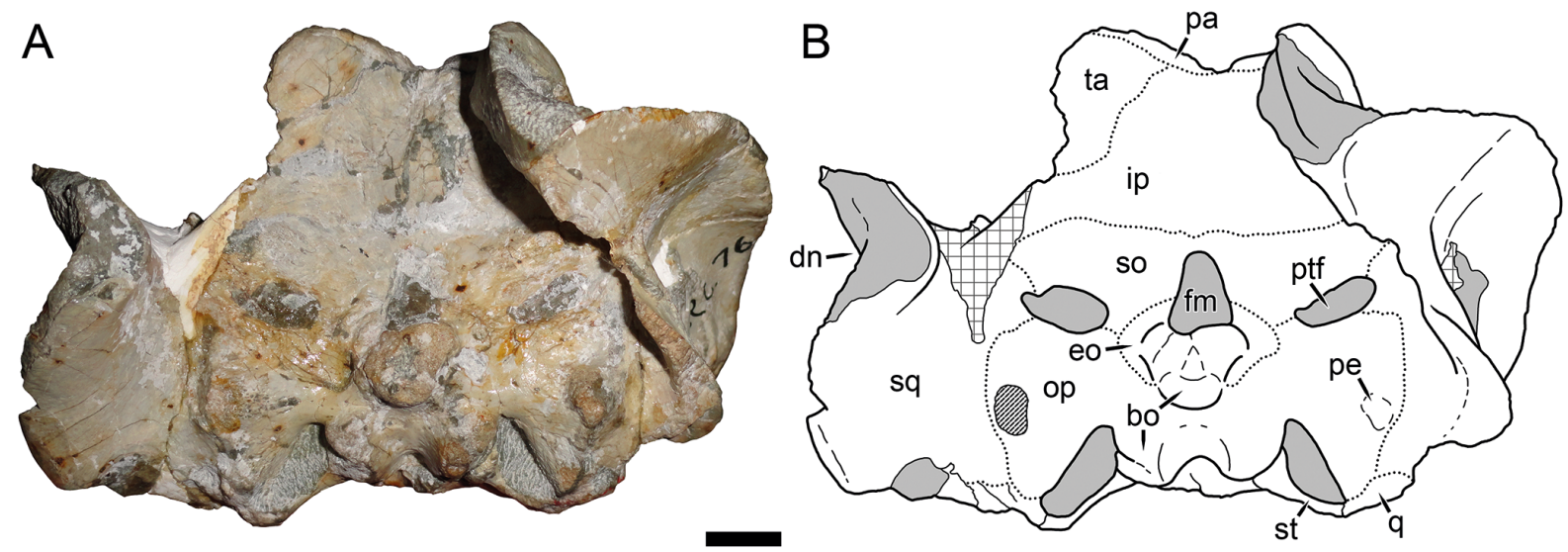

Figure 4. Photograph (a) and interpretive drawing (b) of RC 76, the holotype of Digalodon rubidgei, in occipital view. Gray indicates matrix, hatching indicates damaged bone surface, and cross-hatching indicates plaster. Scale bar equals $1 \mathrm{~cm}$. Abbreviations: bo, basioccipital; dn, dorsolateral notch in squamosal; eo, exoccipital; fm, foramen magnum; ip, interparietal; op, opisthotic; pa, parietal; pe, paroccipital eminence; ptf, post-temporal fenestra; q, quadrate; so, supraoccipital; sq, squamosal; st, stapes; ta, tabular.

to be broadly present across the surface of the premaxilla. Instead, dense concentrations of foramina are only present above the caniniform, strongly suggesting their association with the ever-growing tusk. In other non-mammalian therapsids, vascular foramina commonly occur on the external surface of the maxilla above the canine root and are particularly well developed in the taxa with the largest canines (i.e., gorgonopsians, anteosaurs). Lines of maxillary foramina are also associated with the tooth row in extant reptiles but for the most part are absent in living mammals, even in taxa with enlarged canines (Van Valen, 1960). Instead, mammals typically have a single large maxillary foramen (the infraorbital foramen) through which the infraorbital nerve (associated with mechanoreception of the vibrissae) and artery run (Muchlinski, 2008). Thus, non-mammalian therapsids appear to retain a "reptilian" style of maxillary vasculature primarily associated with the teeth. That said, this does not mean that the beak of Digalodon (and other dicynodonts) lacked a keratinous covering, only that it was not driving foraminal distribution on the skull surface.

In addition to the many small foramina on the lateral maxillary surface, a large vascular foramen is present on the posterior face of the caniniform process in both maxillae (Figs. 2, 3), as in Emydops (Angielczyk et al., 2005, 2009). It is unknown whether small foramina were also present on the medial surface of the maxilla, as this region is overprepared. A labial fossa sensu Angielczyk and Kurkin (2003) is absent. In ventral view, there is a distinct embayment in the maxillary margin anterior to the caniniform process and a postcaniniform keel behind it, as are typical of emydopoids.

The surface of the nasals is damaged, and the position of their anterior contact with the premaxilla is uncertain (Fig. 1). It appears that a lengthy midnasal suture separated the premaxilla from the frontals. The nasals are constricted at midlength by the prefrontals. It is not clear whether nasal bosses were present. An eminence jutting laterally from the right nasal looks superficially like a boss, but is actually just an overhanging bit of bone displaced by shear. If they were present, the nasal bosses would have been small, unlike the expanded bosses typical of cryptodonts. The preserved edges of the nasofrontal suture suggest it ran transversely across the interorbital region in a straight line.

The left prefrontal is damaged (Fig. 2b) but the right one is well preserved (Figs. 1, 2d). The prefrontal makes up the anterodorsal edge of the orbit and makes a significant contribution to the surface of the snout. Ventrally, it has an interdigitated suture with the lacrimal and nasal. Additionally, it has a short ventral contact with a narrow ascending process of the maxilla (Fig. 2d). The lacrimal is a small bone mostly restricted to the anterior orbital wall. It has a small facial contribution between the prefrontal and maxilla and continues ventrally as a thin strip separating the maxilla from the orbit (Fig. 2d). The lacrimal foramen is exposed on the left side of the skull; it is located near the top of the lacrimal and does not exit onto the snout surface.

The jugal is barely visible in lateral view, and in the intact skull would have been exposed only as thin strips at the anteroventral and posteroventral corners of the orbit (Fig. 2). The left jugal is also exposed laterally below the postorbital bar, beneath the squamosal (Fig. 2b), but this is probably due to displacement of the squamosal dorsally - it would have covered this part of the jugal in the undistorted skull. The jugal is more broadly visible in dorsal and ventral views, forming the lateral margin of the subtemporal fenestra.

The frontal is a large bone making up most of the interorbital and a sizable portion of the intertemporal region (Fig. 1). The right frontal makes a relatively short contribution to the orbital margin compared with most emydopoids, but is similar to the condition in Cistecephalus. The broader contribution of the left prefrontal to the orbital margin ap- 
pears to be attributable to damage to the preceding prefrontal, which has been crushed inwards. No postfrontal is present. The frontal has a smooth, uninterrupted border with the postorbital along its lateral edge. Posteriorly, the frontals are separated by a tripartite process made up of the preparietal and paired anterior projections of the parietals. A narrow posterior process of the frontal extends to the level of the pineal foramen.

The postorbital has a narrow anterior process that forms the posterodorsal part of the orbital margin (Figs. 1, 2). The thick postorbital bar appears to be composed entirely of the postorbital bone, without a substantive ventral contribution by the jugal. The posterior ramus of the postorbital is strongly biplanar, with a nearly $90^{\circ}$ angle between its exposure on the skull roof and in the temporal fenestra. Within the temporal fenestra, the postorbital extends to the posterior end of the skull, but is excluded from reaching the occipital edge of the skull roof by a lateral expansion of the parietal (Fig. 2b). The postorbital is also excluded from the back of the skull roof by an extension of the parietal in Kombuisia, Myosaurus, and cistecephalids, but the postorbital contribution to the skull roof is significantly shorter in Digalodon than in those taxa.

The preparietal is a narrow, finger-like element extending forward from the anterior margin of the pineal foramen (Fig. 1). It is nearly equal in length and width to the paired processes of the parietals that flank it, but extends slightly anterior to them in the form of a very thin, attenuate anterior process. The preparietal is flush with the skull roof, following the slope of the intertemporal region posterodorsally. The pineal foramen is located at the junction between the parietals and the preparietal and is an elongate, ovoid opening. It is flanked laterally by swollen, "lip-like" eminences of the parietals (Fig. 1a). These "lips" do not form a complete pineal boss, but are separated by shallow grooves at the posterior and anterior edges of the pineal foramen, as in the enigmatic probable emydopoid Compsodon (Angielczyk et al., 2014). As mentioned above, the parietal expands laterally towards its posterior end, excluding the postorbital from the dorsal skull roof.

The squamosal is the largest bone in the skull, making up most of the zygomatic arch and the lateral margins of the occiput (Figs. 1, 2). The squamosal is displaced anteriorly on the right side of the skull, obscuring the suborbital portions of the maxilla and jugal. It is also displaced dorsally on the left side, exposing part of the subtemporal portion of the jugal. Although the anterior tip of the left squamosal is broken, sutures around the underlying bone indicate that it contacted the maxilla below the orbit. The zygomatic ramus of the squamosal is remarkably tall for an emydopoid and, uniquely in the group, its dorsal edge is thickened and "folded over" (Fig. 2c). This morphology is typical of geikiids (e.g., Aulacephalodon, Pelanomodon), as noted by Cluver and King (1983). Ventral to the zygomatic arch, the squamosal forms a broad plate, overlain anteroventrally by the quadratojugal. In occipital view, there is a dorsolateral notch in the squamosal below the zygomatic arch (Fig. 4), a feature known only in Dicynodontoides, Kombuisia, and Compsodon among emydopoids. The squamosal is a major component of the occiput, making up the lateral borders of the interparietal, supraoccipital, and paroccipital process of the opisthotic. Contact with the tabular is obscured by breakage and matrix, but must have been present. The ventral process of the squamosal completely obscures the quadratojugal posteriorly. The squamosal makes a small contribution to the lateral margin of the post-temporal fenestra. This fenestra is ovoid, angled slightly dorsolaterally, and is at a similar height on the occiput as the foramen magnum. The rest of the fenestra margin is made up of the supraoccipital dorsally and opisthotic ventrally.

The palatine (Fig. 3) is similar in morphology to that of Diictodon or Emydops, and unlike the extremely reduced condition in Dicynodontoides. The expanded anterior portion of the palatine extends laterally, overhanging the internal choana. It lacks the "leaf-shaped" morphology typical of Pristerodon. As in other emydopoids, the palatine surface is relatively smooth, with only fine pitting, unlike the highly rugose palatines of bidentalians. Unlike in Myosaurus, the palatine surface is not pierced by a foramen. Both palatines are displaced in this skull: anteriorly for the right and medially for the left. The ectopterygoid is lateral to the palatine and is similar in size. It has a strongly interdigitated anterior suture with the maxilla.

The vomer is a fused midline element exposed posterior to the secondary palate (Fig. 3). Anteriorly, it forms a narrow rod that is confluent with the posterior median palatal ridge of the premaxilla. Posteriorly, the ventral surface of the vomer diverges into two ridges surrounding the interpterygoid vacuity. This vacuity is obscured by matrix in this specimen, but it is likely that it housed the cultriform process of the parasphenoid as in other dicynodonts.

The anterior rami of the pterygoid are angled anterolaterally (Fig. 3). The left ramus is bent due to distortion, but the right one is mostly straight, unlike the curved rami of Pristerodon and many dicynodontoids. No posteriorly converging ridges are visible on these rami, which is probably the result of overpreparation, as they are clearly present in USNM 22941 (see Fig. 9b). The median pterygoid plate is broad, and a well-developed crista oesophagea was clearly present, but its surface is damaged and partially covered with matrix. The quadrate rami of the pterygoid are poorly preserved. Only the left quadrate ramus is exposed; it is a thin, rod-like structure directed posterolaterally.

Both stapes are preserved in articulation, extending between the quadrate and basal tuber. They are dumbbellshaped and imperforate, as is typical of dicynodonts. Because of overlying matrix, it is uncertain whether a stapedial dorsal process was present: this process is absent in Emydops and Dicynodontoides, but present in basal dicynodonts as well as Kombuisia, Myosaurus, and cistecephalids (Fröbisch, 2007). 
The quadrate and quadratojugal are plate-like elements bearing prominent ventral articular surfaces for contact with the mandible. They are of typical dicynodont morphology (King, 1988; Angielczyk and Rubidge, 2013).

In the basicranium, the parasphenoid, basisphenoid, basioccipital, and opisthotic have fused into a single element. It is unknown whether the prootic is also part of this fused unit, as in some other dicynodonts, as its border cannot be clearly seen in this specimen. The stapedial facet of the basal tuber is angled ventrolaterally, as in other emydopoids. Oddly, the exoccipital does not seem to be completely fused to the other basicranial elements, as a suture with at least the opisthotic is present (Fig. 4). The occipital condyle is tripartite, with a well-developed depression between the basioccipital and two exoccipital portions. The paroccipital process of the opisthotic is transversely short and very tall, with the greatest height at its lateral margin. Near the midheight of its lateral margin, this process bears a knob-like paroccipital eminence (tympanic process of Cox, 1959). This structure is typically well developed in emydopoids, most notably in Emydops, where it forms a spike-like posterior protrusion.

The foramen magnum is roughly triangular, narrowing in height dorsally (Fig. 4). It is surrounded by the exoccipitals at base and supraoccipital at apex. The supraoccipital is a broad, flat element that is narrowest above the foramen magnum. The interparietal is a large, roughly trapezoidal bone making up most of the dorsal portion of the occipital plate. A weak nuchal crest is present on the interparietal midline. The tabular is poorly preserved, with only partial exposure on the left side of the occiput.

\section{Phylogenetic analysis}

We included Digalodon rubidgei in the most recent version (Castanhinha et al., 2013) of the large anomodont data matrix of Kammerer et al. (2011). Digalodon was coded primarily based on the holotype, RC 76, with additional palatal codings based on B 42 and the mandibular codings based on $\mathrm{BP} / 1 / 157$ (see below for discussion of these specimens). The analysis was run in TNT v1.1 (Goloboff et al., 2008), using the same parameters of Castanhinha et al. (2013): Biarmosuchus tener treated as outgroup, all characters treated as unordered, New Technology Search using sectorial searching, parsimony ratchet, drift, and tree fusing, with initial level set at 65 and requiring minimal tree length be found 20 times.

A single most parsimonious tree of length 1006.115 was recovered with a consistency index of 0.239 and retention index of 0.711. Digalodon was found to nest within Emydopoidea as a basal kistecephalian, a position suggested by Broom and Robinson (1948) in their initial description of the taxon. The recovered tree topology is otherwise identical to that of Castanhinha et al. (2013). A condensed version of the tree, showing the position of Digalodon among basal dicynodonts and emydopoids, is shown in Fig. 5. For the expanded

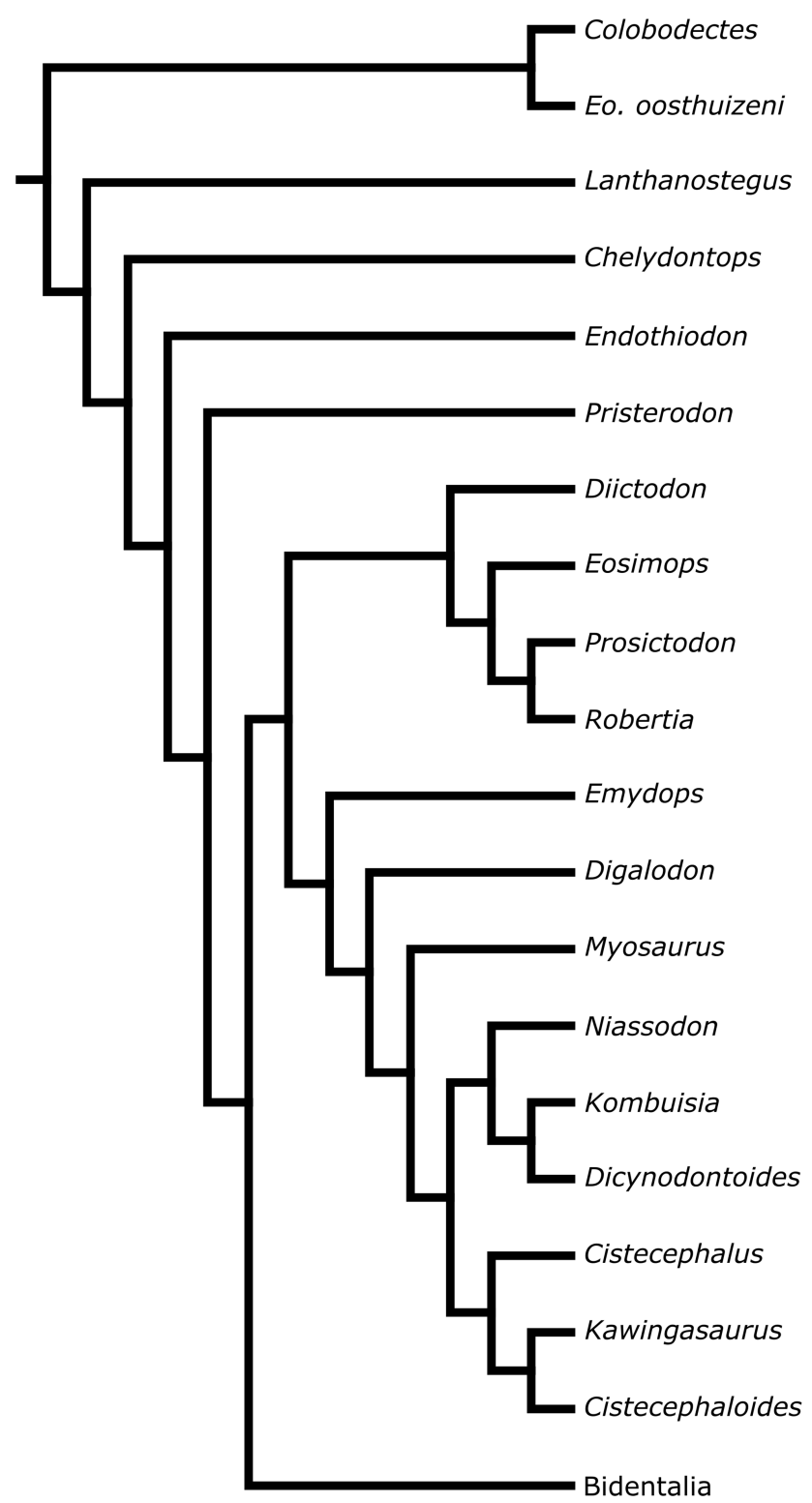

Figure 5. Phylogenetic position of Digalodon rubidgei within Dicynodontia based on the results of the phylogenetic analysis. Eo. = Eodicynodon.

version of the tree, showing the relationships among basal anomodonts and Bidentalia, refer to Castanhinha et al. (2013) or the supplemental materials for this paper.

\section{Discussion}

\subsection{Status of other "large emydopoid" material from Graaff-Reinet}

Although RC 76 was long considered unique, Angielczyk et al. (2009) tentatively referred two additional specimens from the area around Graaff-Reinet (RC 469 and USNM 22941) 

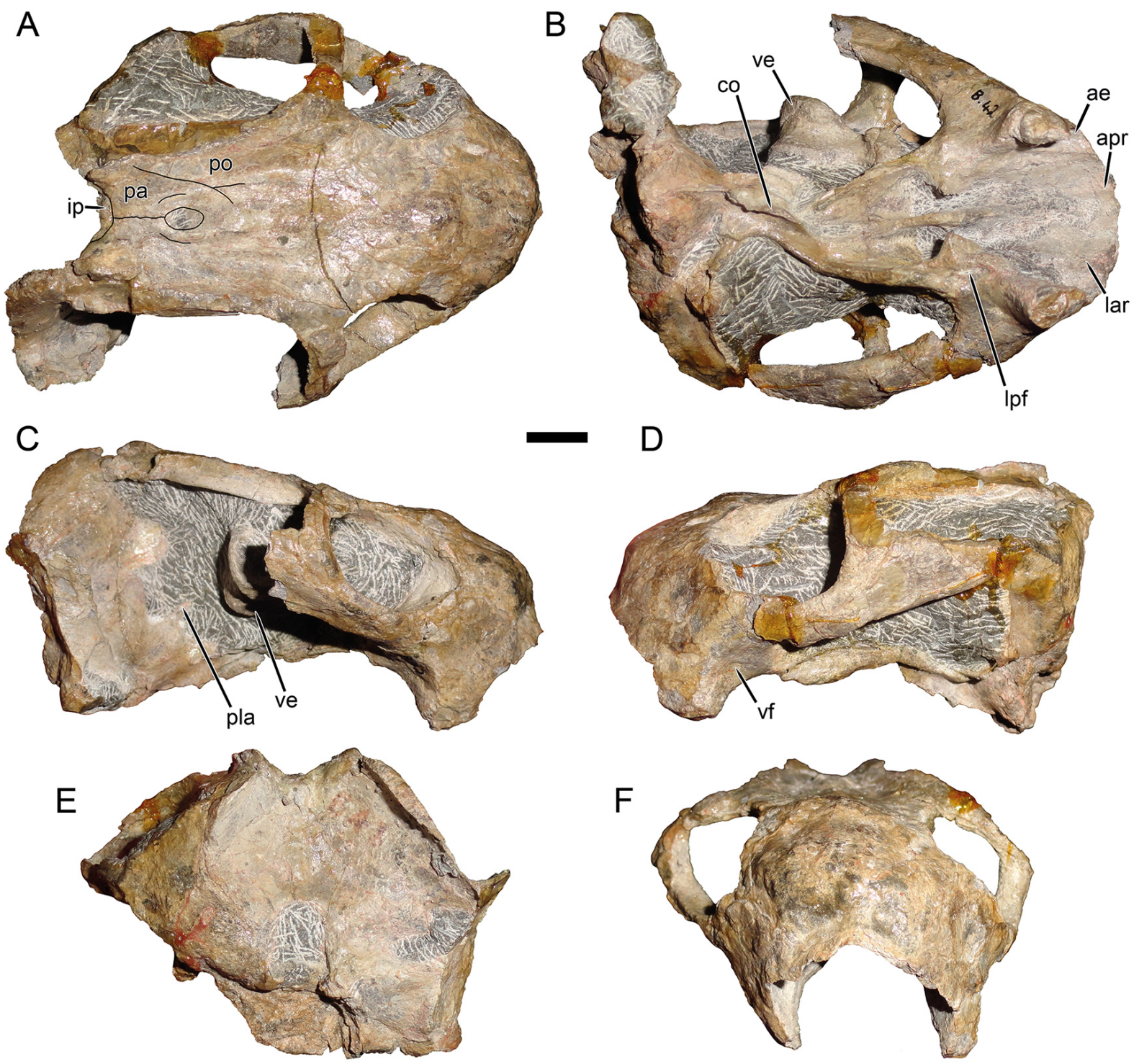

Figure 6. Photographs of B 42, a referred specimen of Digalodon rubidgei, in dorsal (a), palatal (b), right lateral (c), left lateral (d), occipital (e), and anterior (f) views. Scale bar equals $1 \mathrm{~cm}$. Abbreviations: ae, anterior emargination of palatal rim; apr, anterior palatal ridge; co, crista oesophagea; ip, interparietal; lar, lateral anterior palatal ridge; lpf, lateral palatal foramen; pa, parietal; pla, pila antotica; ve, vertebra; vf, vascular foramen.

to Digalodon rubidgei. In our examination of dicynodont material from this area, we have found further emydopoid material that is not referable to Emydops, Dicynodontoides, myosaurids, or cistecephalids. We discuss the status of these specimens below.

There are three specimens we consider definitely referable to Digalodon rubidgei: B 42, BP/1/157, and RC 469. B 42 is a mostly complete but heavily worn skull missing part of the right temporal arch (Fig. 6). The snout is worn off, causing it to appear shorter than it would have been in life. This specimen can be identified as an emydopoid on the basis of an embayment in the palatal rim anterior to the caniniform process.
Additionally, it can be confidently referred to D. rubidgei by the relatively short contribution of the postorbital to the skull roof (Fig. 6a), presence of paired anterior palatal ridges (Fig. 6b), and very tall, thick zygomatic arch (Fig. 6c, d). For the most part, the heavy wear on this skull makes it less morphologically informative than the holotype. However, there are a few areas where it clarifies the morphology of damaged regions of the holotype. Other than a bent basicranial girder (Fig. 6b), B 42 is largely undistorted. Unlike in the holotype, in which an irregular portion of the interparietal is exposed dorsally at the back of the intertemporal bar (Fig. 1), the interparietal of B 42 is restricted to the occiput (Fig. 6a). This 


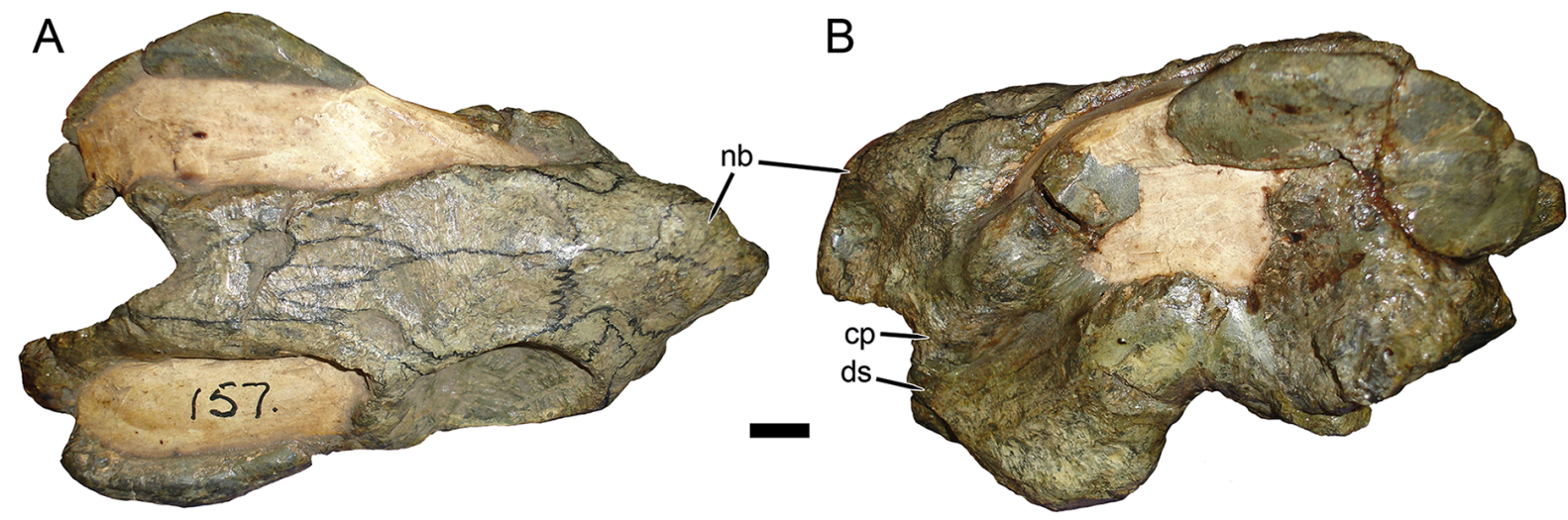

Figure 7. Photographs of BP/1/157, a referred specimen of Digalodon rubidgei, in dorsal (a) and left lateral (b) views. Abbreviations: cp, caniniform process; ds, tip of dentary symphysis; nb, nasal boss. Scale bar equals $1 \mathrm{~cm}$.

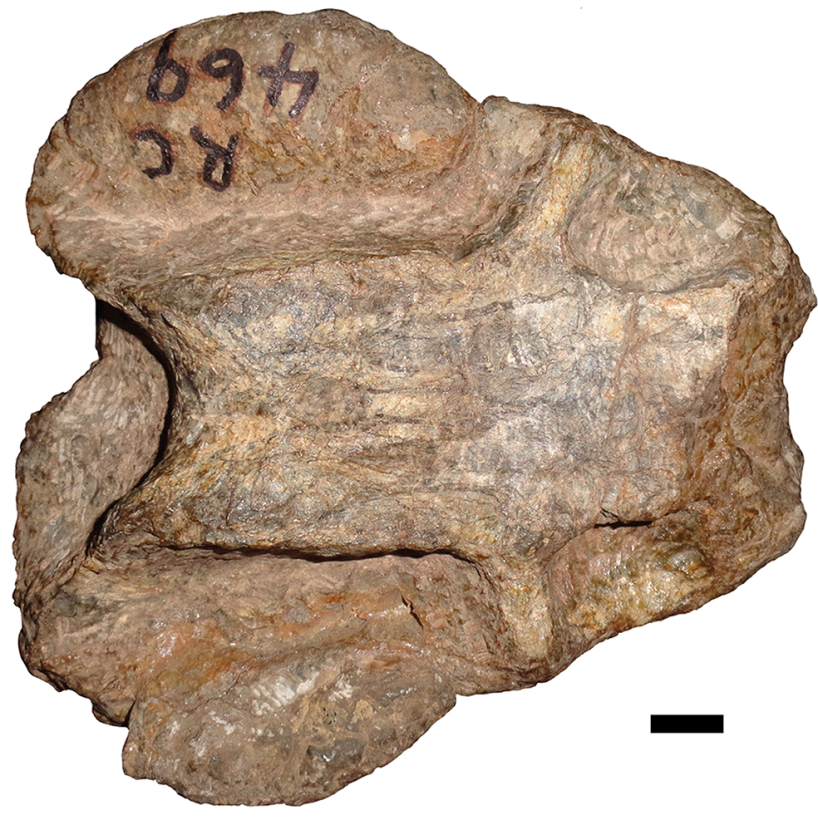

Figure 8. Photograph of RC 469, a specimen referable to Digalodon rubidgei, in dorsal view. Scale bar equals $1 \mathrm{~cm}$.

indicates that the broad contribution of the interparietal to the skull roof in the holotype is not natural, but is the result of the right side of the skull being sheared forward.

The palate of B 42 is better preserved than in the holotype, showing the palatines in their natural orientation and the vomer in three dimensions (Fig. 6b). Unlike the holotype, this specimen preserves clear lateral anterior palatal ridges, which are typical of pylaecephalids and emydopoids. In B 42, they are restricted to the maxilla, but it is likely they originally extended on to the (now worn off) premaxillary tip. An elongate lateral palatal foramen is present between the expanded anterior portion of the palatine and maxilla/ectopterygoid. These foramina are typical of dicynodonts and were probably obscured by crushing in the holotype. Finally, it shows that the crista oesophagea was tall and sharp.

Breakage of the right temporal arch in B 42 has exposed the lateral wall of the braincase (Fig. 6c), a region that is poorly exposed in the holotype. The posterior wall of the temporal fenestra is a flattened plate made up of the squamosal (dorsally), the internal portion of the supraoccipital, and the prootic. It is still uncertain whether the prootic is fused with the opisthotic, as sutures are poorly preserved in this specimen. The prootic bears a distinct, anteriorly directed pila antotica, as is primitive for therapsids. Part of the epipterygoid footplate is preserved ventrolateral to the prootic, but the ascending process (columella) is either broken off or obscured by matrix.

An isolated vertebra is preserved lodged in the right temporal fenestra of B 42 (Fig. 6b, c). It is an unremarkable dicynodont dorsal vertebra. This is the only postcranial material associated with a Digalodon specimen.

$\mathrm{BP} / 1 / 157$ is a distorted and very poorly prepared skull, but importantly and uniquely among Digalodon specimens it preserves the mandible (Fig. 7b). This specimen can be identified as $D$. rubidgei on the basis of its relatively long "beak" that is sharply demarcated from the caniniform process, tall zygomatic arch, and exclusion of the postorbital from the posterior skull roof by a lateral expansion of the parietal. The mandibular symphysis is typically emydopoid, with a tall, shovel-like beak tip. A mandibular fenestra overlain by a lateral dentary shelf is present, although the morphology of this shelf cannot be determined due to damage. This specimen also preserves the nasal bosses, and demonstrates that only a small median boss was present, as in nearly all non-bidentalian dicynodonts.

RC 469 is a very incompletely prepared partial skull (Fig. 8) with its snout broken off at the level of the tusks (a section through the tusk roots can be seen in anterior view). It can be identified as Digalodon rubidgei on the basis of the lateral parietal expansion excluding the postorbital from the 

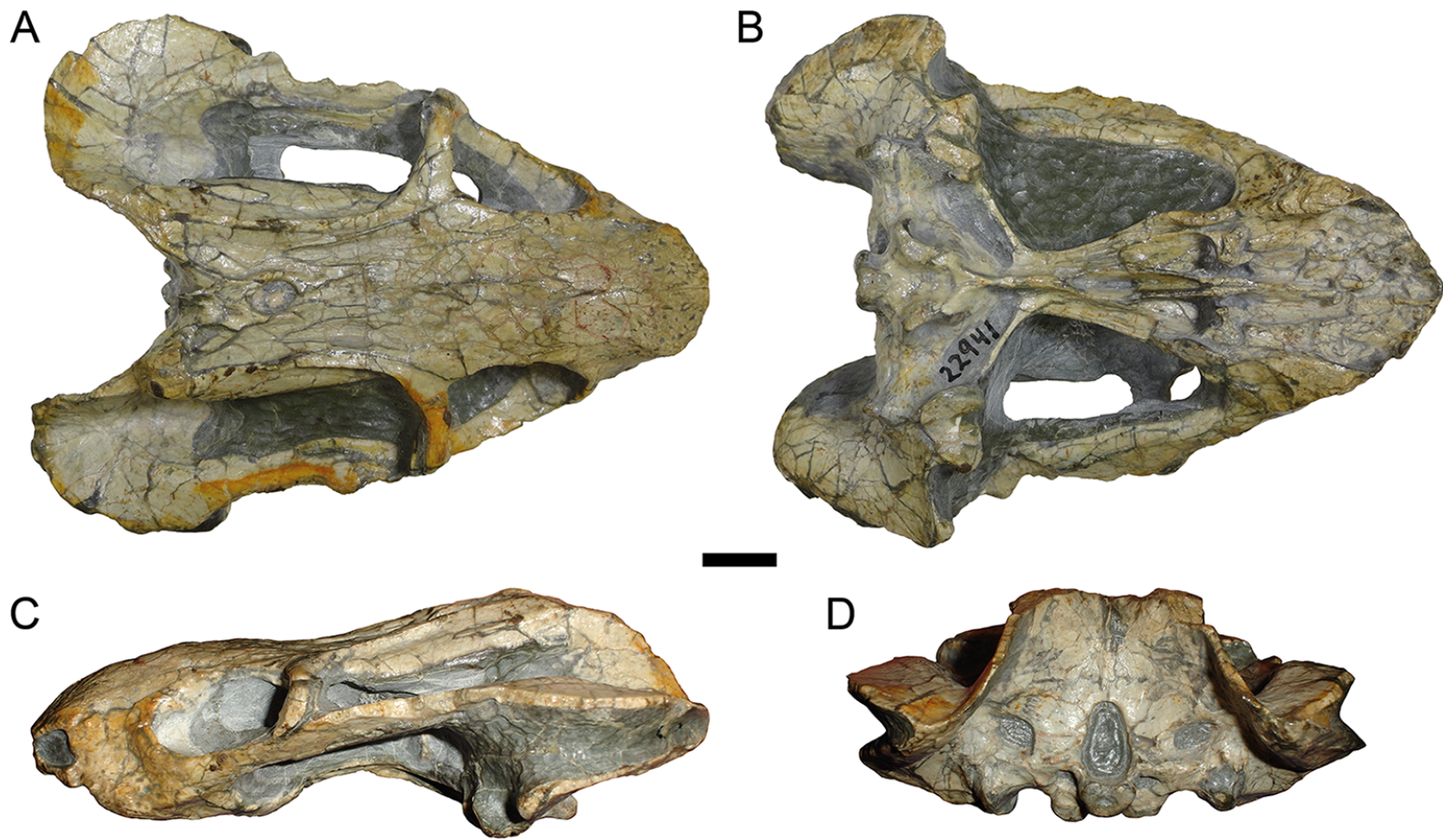

Figure 9. USNM 22941, a "large emydopoid" from Richmond considered a possible sexually dimorphic female of Digalodon rubidgei in dorsal (a), palatal (b), left lateral (c), and occipital (d) views. Scale bar equals $1 \mathrm{~cm}$.
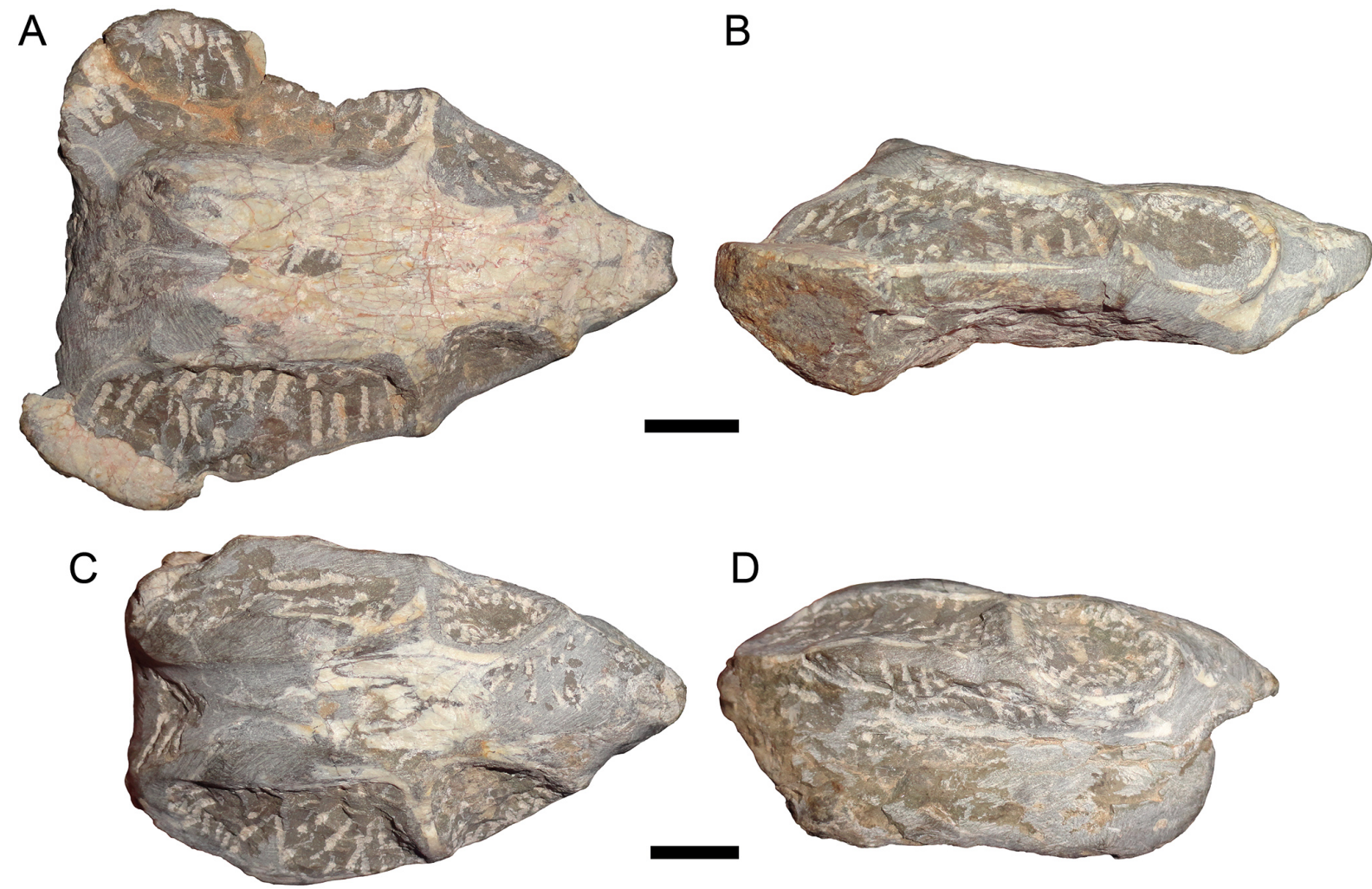

Figure 10. Specimens tentatively considered juvenile representatives of Digalodon rubidgei. RC 303 in dorsal (a) and right lateral (b) views. RC 306 in dorsal (c) and right lateral (d) views. Scale bars equal $1 \mathrm{~cm}$. 
back of the skull roof. The morphologies of the preparietal and flanking anterior parietal processes in this specimen are nearly identical to that of the holotype.

There are several other specimens that we have identified that may also represent Digalodon rubidgei, but they show some differences that prevent us from definitively referring them to the genus at this time. USNM 22941 is a somewhat dorsoventrally flattened specimen with a worn-off ventral margin to the snout (Fig. 9). This specimen is clearly an emydopoid (precaniniform embayment present), but general skull proportions preclude a myosaurid or cistecephalid identification. The broad intertemporal region is unlike kingoriids, and it is larger than any known individual of Emydops. USNM 22941 exhibits the posterior expansion of the parietal (excluding the postorbital from the back of the skull roof) here considered characteristic of Digalodon rubidgei among emydopoids. However, it differs from the previously discussed specimens of D. rubidgei in several striking features. Although a weak raised edge is present around the pineal foramen, no swollen, "lip-like" structure is present the intertemporal region is fairly flat (although angled upwards posteriorly, as in RC 76). Also, the zygomatic ramus of the squamosal is very dorsoventrally thin compared to the other specimens of D. rubidgei. It could be possible to explain this difference by taphonomic distortion, with the apparently "taller" zygoma being the result of crushing. However, although this could be invoked for RC 76 and BP/1/157, it cannot explain the presence of this morphology in the nearly undistorted B 42. Furthermore, the thickened dorsal margin of the zygoma in RC 76 cannot be explained taphonomically, considering that its edge is downturned perpendicular to the direction of shear in the skull. As such, we consider the differences in morphology between the zygoma of RC 76 and USNM 22941 to be real.

Unlike all previously discussed specimens, USNM 22941 clearly lacks tusks. Sexually dimorphic absence in tusks is known in the pylaecephalid Diictodon feliceps (Sullivan et al., 2003; Sullivan and Reisz, 2005). Intriguingly, Sullivan and Reisz (2005) also argued that pineal boss development is sexually dimorphic in Diictodon. Development of the thickened, rugose zygoma in Aulacephalodon has also been considered a sexually dimorphic feature (Tollman et al., 1980). It is possible, then, that Digalodon rubidgei was an extremely sexually dimorphic taxon, with males (represented by RC 76, $\mathrm{RC} 469$, B 42, and BP/1/157) bearing tusks and having a swollen pineal region and tall, thickened zygoma, whereas females (represented by USNM 22941) lacked tusks and had a flat pineal region and narrow zygoma. More material is required to address this issue.

Several additional small, incompletely prepared specimens (RC 303, 304, and 306) closely resemble USNM 22941 and may also represent Digalodon rubidgei (Fig. 10). These specimens all have a thin zygomatic arch; given their significantly smaller size than the specimens discussed above, their

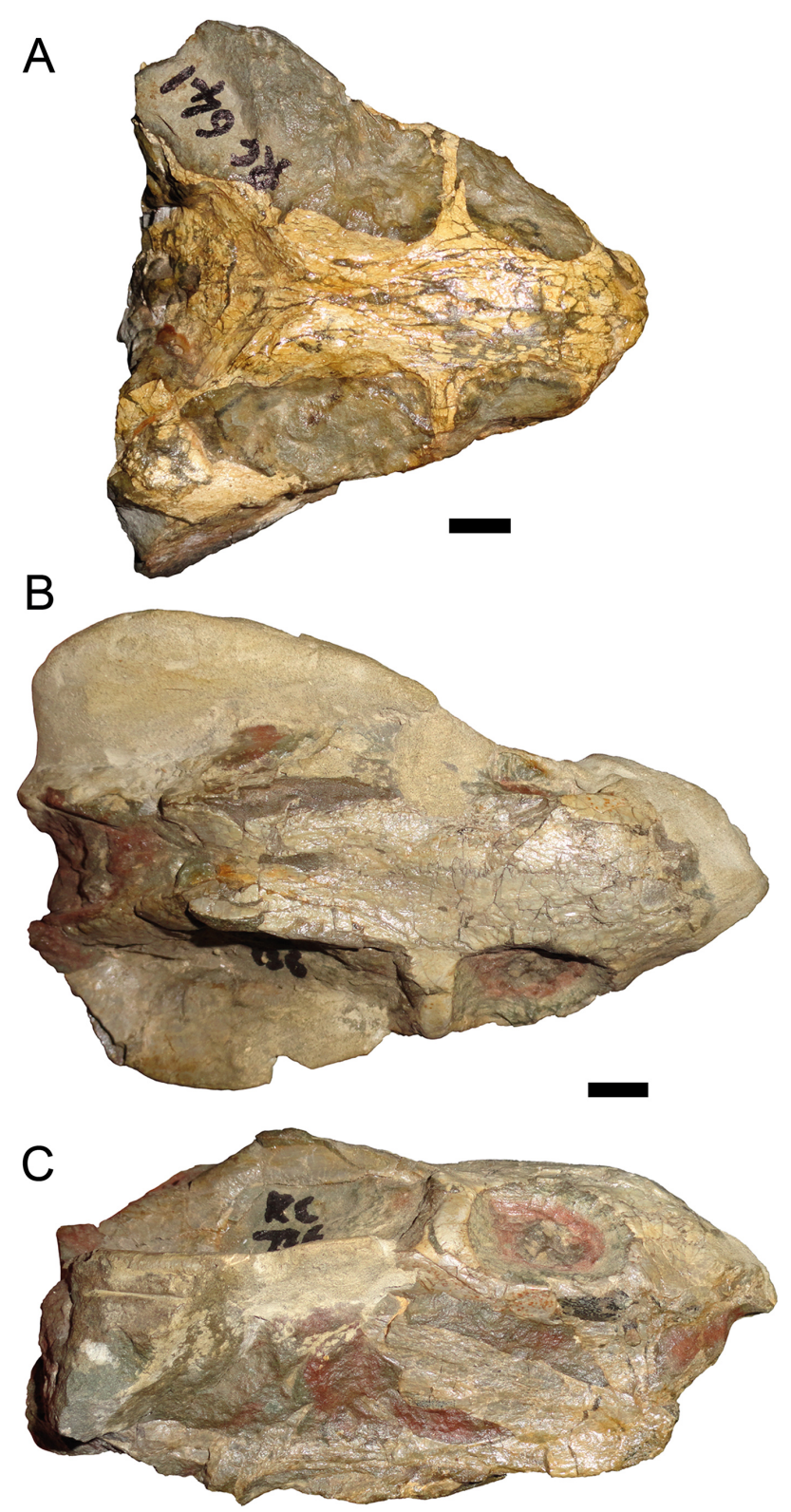

Figure 11. Photographs of "large emydopoid" material from the Graaff-Reinet area referable to Compsodon helmoedi. RC 641, a specimen referable to Compsodon helmoedi in dorsal (a) view. RC 736, a specimen referable to Compsodon helmoedi in dorsal (b) and right lateral (c) views. Scale bars equal $1 \mathrm{~cm}$.

lack of what we interpret as a secondary sexual feature in $D i$ galodon could be attributable to immaturity rather than sex.

Two other "large emydopoid" specimens from GraaffReinet with swollen intertemporal regions are worth considering. RC 641 is a partially prepared skull from Ferndale, Graaff-Reinet (Fig. 11a). The smaller of the two skulls, it has suffered anterior shear of the skull roof. RC 736 is a damaged skull from Boskraal, Graaff-Reinet (Fig. 11b, c). Like Digalodon, these have a broad intertemporal bar at its anterior end 
(unlike kingoriids). However, instead of having a swollen region formed by the parietal, as in Digalodon, the swollen portion in these specimens represents expansion of the postorbitals, greatly constricting the exposure of the parietals posterior to the pineal foramen. This morphology is typical of Compsodon helmoedi (Angielczyk et al., 2014), and we suggest that these specimens represent additional South African specimens of this poorly known taxon. Unfortunately, poor preservation of these specimens obscures whether they had a distinct postorbital (present in Compsodon, but absent in Digalodon). This identification will be considered in further detail in a complete description of the Zambian material of $C$. helmoedi, currently under preparation.

\subsection{Stratigraphic and geographic range of Digalodon rubidgei}

Even if the tentatively referred "female" and "subadult" specimens are taken into consideration, Digalodon specimens are restricted to a very narrow portion of the Karoo Basin, being found only in the central basin near the junction between the Western, Eastern, and Northern Cape provinces, primarily in the Camdeboo Local Municipality surrounding Graaff-Reinet. These strata represent a limited temporal range, covering the upper Cistecephalus AZ and Dicynodon $\mathrm{AZ}$, and yield a unique, localized dicynodont fauna. In addition to Digalodon, all known specimens of Pelanomodon (Broom, 1938), Kitchinganomodon (Maisch, 2002), Keyseria, and Basilodon (Kammerer et al., 2011) have been found in this area. Intriguingly, the rare dicynodont Compsodon is also part of this fauna; this taxon has recently been found to be a component of the therapsid fauna of the Upper Madumabisa Mudstone Formation of Zambia (Angielczyk et al., 2014), potentially allowing for finer correlation of the Zambian fauna with this narrow section of the Beaufort Group.

Acknowledgements. For access to specimens in their care, we thank Matt Carrano (USNM), Sheena Kaal (SAM), Anziske Kayster (B), Richard and Marion Rubidge (RC), and Bernhard Zipfel (BP). C. F. Kammerer and J. Fröbisch are supported by a Sofja Kovalevskaja Award from the Alexander von Humboldt Foundation, awarded to J. Fröbisch. We thank Jun Liu and Christian Sidor for their helpful reviews of this manuscript.

Edited by: D. Korn

Reviewed by: J. Liu and C. Sidor

\section{References}

Angielczyk, K. D.: Preliminary phylogenetic analysis and stratigraphic congruence of the dicynodont anomodonts (Synapsida: Therapsida), Pal. Afr., 37, 53-79, 2001.

Angielczyk, K. D.: New specimens of the Tanzanian dicynodont "Cryptocynodon" parringtoni von Huene, 1942 (Therapsida,
Anomodontia), with an expanded analysis of Permian dicynodont phylogeny, J. Vert. Paleontol., 27, 116-131, 2007.

Angielczyk, K. D. and Kurkin, A. A.: Phylogenetic analysis of Russian Permian dicynodonts (Therapsida: Anomodontia): implications for Permian biostratigraphy and Pangaean biogeography, Zool. J. Linn. Soc., 139, 157-212, 2003.

Angielczyk, K. D. and Rubidge, B. S.: Skeletal morphology, phylogenetic relationships, and stratigraphic range of Eosimops newtoni Broom, 1921, a pylaecephalid dicynodont (Therapsida, Anomodontia) from the Middle Permian of South Africa, J. Sys. Palaeontol., 11, 189-229, 2013.

Angielczyk, K. D., Fröbisch, J., and Smith, R. M. H.: On the stratigraphic range of the dicynodont taxon Emydops (Therapsida: Anomodontia) in the Karoo Basin, South Africa, Pal. Afr., 41, 23-33, 2005.

Angielczyk, K. D., Sidor, C. A., Nesbitt, S. J., Smith, R. M. H., and Tsuji, L. A.: Taxonomic revision and new observations on the postcranial skeleton, biogeography, and biostratigraphy of the dicynodont genus Dicynodontoides, the senior subjective synonym of Kingoria (Therapsida, Anomodontia), J. Vert. Paleontol., 29, 1174-1187, 2009.

Angielczyk, K. D., Steyer, J.-S., Sidor, C. A., Smith, R. M. H., Whatley, R., and Tolan, S.: Permian and Triassic dicynodont (Therapsida: Anomodontia) faunas of the Luangwa Basin, Zambia: taxonomic update and implications for dicynodont biogeography and biostratigraphy, in: Early Evolutionary History of the Synapsida, edited by: Kammerer, C. F., Angielczyk, K. D., and Fröbisch, J., Dordrecht, Springer, 2014.

Brink, A. S.: Illustrated bibliographic catalogue of the Synapsida, Handbook of the South African Geological Survey, No. 10, 1986.

Broom, R.: On the use of the term Anomodontia, Rec. Albany Mus., 1, 266-269, 1905.

Broom, R.: On two new anomodont genera, Ann. Transvaal Mus., 19, 247-250, 1938.

Broom, R. and Robinson, J. T.: Some new fossil reptiles from the Karoo Beds of South Africa, Proc. Zool. Soc. London, 118, 392407, 1948.

Castanhinha, R., Araújo, R., Júnior, L. C., Angielczyk, K. D., Martins, G. G., Martins, R. M. S., Chaouiya, C., Beckmann, F., and Wilde, F.: Bringing dicynodonts back to life: paleobiology and anatomy of a new emydopoid genus from the Upper Permian of Mozambique, PLoS ONE, 8, e80974, doi:10.1371/journal.pone.0080974, 2013.

Cluver, M.: The skeleton of the mammal-like reptile Cistecephalus with evidence of a fossorial mode of life, Ann. S. Afr. Mus., 76, 213-246, 1978.

Cluver, M. A. and King, G. M.: A reassessment of the relationships of Permian Dicynodontia (Reptilia, Therapsida) and a new classification of dicynodonts, Ann. S. Afr. Mus., 91, 195-273, 1983.

Cox, C. B.: On the anatomy of a new dicynodon genus with evidence of the position of the tympanum, Proc. Zool. Soc. London, 132, 321-367, 1959.

Cox, C. B.: A new digging dicynodont from the Upper Permian of Tanzania, in: Studies in Vertebrate Evolution, edited by: Joysey, K. A. and Kemp, T. S., Edinburgh, Oliver and Boyd, 1972.

Cox, C. B. and Angielczyk, K. D.: A new endothiodont dicynodont (Therapsida, Anomodontia) from the Permian Ruhuhu Formation (Songea Group) of Tanzania and its feeding system, J. Vert. Paleontol., in press, 2015. 
Fröbisch, J.: The cranial anatomy of Kombuisia frerensis Hotton (Synapsida, Dicynodontia) and a new phylogeny of anomodont therapsids, Zool. J. Linn. Soc., 150, 117-144, 2007.

Fröbisch, J. and Reisz, R. R.: A new species of Emydops (Synapsida, Anomodontia) and a discussion of dental variability and pathology in dicynodonts, J. Vert. Paleontol., 28, 770-787, 2008.

Goloboff, P. A., Farris, J. S., and Nixon, K. C.: TNT, a free program for phylogenetic analysis, Cladistics, 24, 774-786, 2008.

Hammer, W. R. and Cosgriff, J. W.: Myosaurus gracilis, an anomodont reptile from the Lower Triassic of Antarctica and South Africa, J. Paleontol., 55, 410-424, 1981.

Haughton, S. H. and Brink, A. S.: A bibliographical list of Reptilia from the Karroo beds of Africa, Palaeontol. Afr., 2, 1-187, 1954.

Kammerer, C. F. and Angielczyk, K. D.: A proposed higher taxonomy of anomodont therapsids, Zootaxa, 2018, 1-24, 2009.

Kammerer, C. F., Angielczyk, K. D., and Fröbisch, J.: A comprehensive taxonomic revision of Dicynodon (Therapsida, Anomodontia) and its implications for dicynodont phylogeny, biogeography, and biostratigraphy, Soc. Vert. Paleontol. Memoir, 11, 1158, 2011.

Kammerer, C. F., Angielczyk, K. D., and Fröbisch, J.: On the validity and phylogenetic position of Eubrachiosaurus browni, a kannemeyeriiform dicynodont (Anomodontia) from Triassic North America, PLoS ONE, 8, e64203, doi:10.1371/journal.pone.0064203, 2013.

Kemp, T. S.: Mammal-like Reptiles and the Origin of Mammals, London, Academic Press, 1982.

King, G. M.: Anomodontia, 17C, in: Handbuch der Paläoherpetologie, edited by: Wellnhofer, P., Stuttgart, Gustav Fischer Verlag, 1988.

Lehman, J.-P.: Dicynodontia, in: Traité de Paléontologie VI(i), edited by: Piveteau, J., Paris, Mason et Cie, 1961.

Maisch, M.: Observations on Karoo and Gondwana vertebrates. Part 4: The taxonomic status of the Late Permian rhachiocephalid Platycyclops crassus Broom, 1948 (Therapsida: Dicynodontia) from the South African Karoo, N. Jahrb. Geol. Paläontol. Monat., 2002, 362-372, 2002.

Muchlinski, M. N.: The relationship between the infraorbital foramen, infraorbital nerve, and maxillary mechanoreception: implications for interpreting the paleoecology of fossil mammals based on infraorbital foramen size, Anat. Rec., 291, 1221-1226, 2008.
Owen, R.: Report on the Reptilian Fossils of South Africa. Part I. - Description of certain fossil crania, discovered by A. G. Bain, Esq., in sandstone rocks at the south-eastern extremity of Africa, referable to different species of an extinct genus of Reptilia ( $D i$ cynodon), and indicative of a new Tribe or Sub-order of Sauria, Trans. Geol. Soc. London, 2nd Series 7, 59-84, 1845.

Owen, R.: On the orders of fossil and recent Reptilia, and their distribution in time, Rept. British Assoc. Adv. Sci., 1859, 153-166, 1860a.

Owen, R.: On some reptilian fossils from South Africa, Quart. J. Geol. Soc. London, 16, 49-63, 1860 b.

Owen, R.: Descriptive and Illustrated Catalogue of the Fossil Reptilia of South Africa in the Collection of the British Museum, London, Taylor and Francis, 1876.

Romer, A. S.: Osteology of the Reptiles, Chicago, University of Chicago Press, 1956.

Smith, R. M. H. and Botha-Brink, J.: Anatomy of a mass extinction: Sedimentological and taphonomic evidence for drought-induced die-offs at the Permo-Triassic boundary in the main Karoo Basin, South Africa, Palaeogeogr. Palaeoclimatol. Palaeoecol., 396, 99118, 2014.

Smith, R., Rubidge, B., and van der Walt, M.: Therapsid biodiversity patterns and paleoenvironments of the Karoo Basin, South Africa, in: Forerunners of Mammals: Radiation, Histology, Biology, edited by: Chinsamy-Turan, A., Bloomington, Indiana University Press, 2012.

Sullivan, C., Reisz, R. R., and Smith, R. M. H.: The Permian mammal-like herbivore Diictodon, the oldest known example of sexually dimorphic armament, Proc. R. Soc. London B, 270, 173-178, 2003.

Sullivan, C. and Reisz, R. R.: Cranial anatomy and taxonomy of the Late Permian dicynodont Diictodon, Ann. Carnegie Mus., 74, 45-75, 2005.

Tollman, S. M., Grine, F. E., and Hahn, B. D.: Ontogeny and sexual dimorphism in Aulacephalodon (Reptilia, Anomodontia), Ann. S. Afr. Mus., 81, 159-186, 1980.

van Hoepen, E. C. N.: Oor die indeling van die Dicynodontidae na aanleiding van nuew vorme, Paleontologiese Navorsing van die Nasionale Museum, 2, 67-101, 1934.

Van Valen, L.: Therapsids as mammals, Evolution, 14, 304-313, 1960 . 